\title{
Effect of heparin and low molecular weight heparins on thrombin-induced blood platelet activation in the absence of antithrombin III
}

Citation for published version (APA):

Baruch, D., Franssen, J., Hemker, H. C., \& Lindhout, T. (1985). Effect of heparin and low molecular weight heparins on thrombin-induced blood platelet activation in the absence of antithrombin III. Thrombosis Research, 38(5), 447-458. https://doi.org/10.1016/0049-3848(85)90178-1

Document status and date:

Published: 01/06/1985

DOI:

10.1016/0049-3848(85)90178-1

Document Version:

Publisher's PDF, also known as Version of record

Please check the document version of this publication:

- A submitted manuscript is the version of the article upon submission and before peer-review. There can be important differences between the submitted version and the official published version of record.

People interested in the research are advised to contact the author for the final version of the publication, or visit the DOI to the publisher's website.

- The final author version and the galley proof are versions of the publication after peer review.

- The final published version features the final layout of the paper including the volume, issue and page numbers.

Link to publication

\footnotetext{
General rights rights.

- You may freely distribute the URL identifying the publication in the public portal. please follow below link for the End User Agreement:

www.umlib.nl/taverne-license

Take down policy

If you believe that this document breaches copyright please contact us at:

repository@maastrichtuniversity.nl

providing details and we will investigate your claim.
}

Copyright and moral rights for the publications made accessible in the public portal are retained by the authors and/or other copyright owners and it is a condition of accessing publications that users recognise and abide by the legal requirements associated with these

- Users may download and print one copy of any publication from the public portal for the purpose of private study or research.

- You may not further distribute the material or use it for any profit-making activity or commercial gain

If the publication is distributed under the terms of Article $25 \mathrm{fa}$ of the Dutch Copyright Act, indicated by the "Taverne" license above, 
EFFECT OF HEPARIN AND LOW MOLECULAR WEIGHT HEPARINS ON THROMBIN-INDUCED BLOOD PLATELET ACTIVATION IN THE ABSENCE OF ANTITHROMBIN III

Dominique Baruch, Jo Franssen, H. Coenraad Hemker and Theo Lindhout Department of Biochemistry, Biomedical Center, Rijksuniversiteit Limburg, 6200 MD Maastricht, The Netherlands.

(Received 22.1.1985; Accepted in revised form 22.2.1985 by Editor G. De Gaetano)

ABSTRACT

We have investigated the antithrombin III independent effect of crude heparin, two heparin fractions and a heparinoid on in vitro thrombin-induced platelet activation. Thrombin-induced platelet factor $\mathrm{Va}$ generation and thrombin plus collagen-induced platelet prothrombin converting activity were tested. Crude heparin was a more potent inhibitor of these reactions than the fractions or the heparinoid. The inhibitory action of the heparins was found to be the result of a direct effect on thrombin and not of an effect either on platelet activation functions or on the assembly or functioning of the prothrombinase complex. Probably this heparin inhibition is due to the masking of secondary macromolecular substrate binding sites on the thrombin molecule. We found no correlation between IC $_{50}$ values and the antithrombin III-dependent antithrombin specific activities of the heparins. This supports the notion that heparin properties other than their affinity for antithrombin III may contribute to the action of this drug in blood coagulation.

\section{INTRODUCTION}

Heparin is an effective antithrombotic agent, widely used in the treatment and prophylaxis of venous thrombosis and thromboembolism. However, its clinical use is limited by its major side effect, bleeding. For many years, it was generally assumed that both the antithrombotic and hemorrhagic properties of heparin are related to its ability to augment the reactions between activated coagulation factors and antithrombin III. More recently, numerous comparative studies on the hemorrhagic, antithrombotic and anticoagulant effects of heparinoids and low molecular weight heparin fractions, prepared from crude heparin by a variety of methods, indicate that: 1) low molecular weight heparins with an anti-factor Xa to anti-thrombin

Key words : Thrombin, heparin, LMW heparin, platelet coagulant activities. 
ratio, larger than that of crude heparin, have similar antithrombotic activities but produce less hemorrhage (1), 2) The anti-factor Xa activity of heparin is not related to its antithrombotic activity $(2,3)$, 3) The excess low affinity material present in heparin with a low affinity to antithrombin III increases hemorrhage, without having either in vivo antithrombotic or ex vivo anticoagulant activity (4) and 4) Dermatan sulfate, known to potentiate only the activity of heparin cofactor II on thrombin, has an antithrombotic activity equal to that of crude heparin but leaves hemostasis largely unaffected (5).

These studies illustrate the difficulty in attempting to correlate in vitro assays and in vivo blood changes. It can be questioned whether one has to search for other, more specific markers of the anti-thrombin effect of heparin, that could be either an antithrombin III-dependent or independent one. In this context it is important to note that coagulation and platelet reactions are strongly coupled by a positive feedback mechanism because thrombin-induced platelet activation generates procoagulant activities. This thrombin-dependent mechanism leads to an important amplification of thrombin generation and so of both hemostatic plug and thrombus formation.

The present study was undertaken to determine to what extent heparin(fractions) inhibit the formation of thrombin-induced platelet procoagulant activities and to investigate whether heparin(fractions) exert such an anti-thrombin activity through a mechanism that is independent of antithrombin III.

\section{MATERIAL AND METHODS}

S 2238 ( $\mathrm{H}-\mathrm{D}-\mathrm{Phe}-\mathrm{Pi}-\mathrm{prg}-\mathrm{pNa}$ ) was purchased from AB Kabi Diagnostica, Stockholm, Sweden. Fatty acid free human serum albumin (HSA), Russel1's Viper Venom and Echis Carinatus venom were obtained from Sigma. Horse tendon collagen was obtained from Hormon-Chemie Mïnchen, Germany. It was added in the non-fibrillar form dissolved in acidic dilution buffer obtained from. Hormon-Chemie. Reaction tubes were $2 \mathrm{ml}$ plastic flat-bottom tubes obtained from Sterilin Ltd (Teddington, England). Teflon-coated magnetic spinning bars $7 \times 2 \mathrm{~mm}$ were from Bel-Art Products, USA. Phosphatidylcholine (18:1 cis/18:1 cis phosphatidylcholine) was from Sigma, USA. A11 reagents used were of the highest grade commercially available.

Preparation of Phospholipids and Phospholipid Vesicles. Phosphatidylserine (18:1 cis/18:1 cis) was prepared from phosphatidylcholine by enzymatic synthesis according to the method of Comfurius and Zwaal (6). Single bilayer vesicle solutions were prepared as previously described (7). Phospholipid concentrations were determined by phosphate analysis according to Böttcher et al. (8).

Proteins. Bovine prothrombin, factor $\mathrm{X}$, factor $\mathrm{Xa}$, factor $\mathrm{V}$ and factor Va were purified according to established procedures (9). Human and bovine $\alpha$-thrombin were prepared as described by Pletcher et al. (10). The specific clotting activity was $2800 \mathrm{NIH} \mathrm{U/mg} \mathrm{for} \mathrm{human} \mathrm{thrombin} \mathrm{and} 2200 \mathrm{NIH} \mathrm{U/mg}$ for bovine thrombin. The protein preparations were stored at $-70{ }^{0} \mathrm{C}$ after dialysis against $50 \mathrm{mM}$ Tris/HCl $175 \mathrm{mM} \mathrm{NaCl}$ at $\mathrm{pH} 7.9$.

Protein Concentrations. Concentrations of thrombin and factor Xa were determined by active site titration with p-nitrophenyl-p-guanidinobenzoate hydrochloride (11). Prothrombin concentrations were determined after 
complete activation with E.carinatus venom followed by active site titration. Similarly, factor X concentrations were obtained by active site titration after complete activation with factor X - converting protein from Russell's viper venom (11). Factor Va concentrations were determined by kinetic analysis (9).

Heparin and Heparin Fractions. Crude porcine intestinal mucosal heparin (MW 1500-30000, mean MW 15000, anti Xa and anti IIa activity $175 \mathrm{U} / \mathrm{mg}$ ) was obtained from Organon Laboratories (Oss, the Netherlands). The following low molecular weight compounds were prepared from standard heparin by Choay Institute (Paris): CY 216, a calcium salt was obtained by ethanol extraction (mean MW 4500, USP activity $50 \mathrm{U} / \mathrm{mg}$, anti Xa activity $200 \mathrm{U} / \mathrm{mg}$, anti IIa activity $10-20 \mathrm{U} / \mathrm{mg}$ ) and CY 222, a sodium salt was obtained by nitrous acid depolymerization (mean MW 2500, USP activity $25 \mathrm{U} / \mathrm{mg}$, anti Xa activity $250 \mathrm{U} / \mathrm{mg}$, anti IIa activity 5-15 U/mg). Org 10172, a sulphated mucopolysaccharide was isolated by Organon Laboratories (Oss, the Netherlands) from porcine intestinal mucosa (mean MW 6400, USP activity $2.94 \mathrm{U} / \mathrm{mg}$, anti Xa activity $8 \mathrm{U} / \mathrm{mg}$, anti IIa activity $0.32 \mathrm{U} / \mathrm{mg}$ ).

Isolation of Human Platelets. Blood was drawn by venepuncture from healthy male volunteers who had not taken any medication for at least one week. As anticoagulant, one volume of acid citrate/dextrose $(0.18 \mathrm{M}$ glucose/0.08 $\mathrm{M}$ sodium citrate/0.052 M citric acid) was added to 5 volumes of whole blood. Platelet-rich plasma was obtained after centrifuging at $220 \mathrm{xg}$ for $15 \mathrm{~min}$. Platelets were isolated by centrifuging at $600 \mathrm{xg}$ for $20 \mathrm{~min}$ and the pellet was resuspended in a Hepes buffer containing $136 \mathrm{mM} \mathrm{NaCl}, 2.68 \mathrm{mM} \mathrm{KCl}, 2 \mathrm{mM}$ $\mathrm{MgCl}_{2}, 10 \mathrm{mM}$ Hepes, $5 \mathrm{mM}$ glucose and $0.4 \%$ HSA, pH 6.7. The platelets were washed twice in this buffer by centrifuging $350 \mathrm{xg}, 15 \mathrm{~min}$. Before centrifuging acid citrate/dextrose was added to the suspension ( 1 vol. to 14 vol.). Finally the platelets were resuspended in the Hepes buffer at $\mathrm{pH} 7.5$ containing $0.1 \%$ HSA. The entire procedure for platelet preparation took about $2 \mathrm{~h}$ and was carried out at room temperature $\left(22{ }^{\mathrm{O}} \mathrm{C}\right)$. Platelet concentration was determined with a Coulter counter. Platelets were kept at room temperature and no loss of platelet functions was found for at least $15 \mathrm{~h}$.

Determination of Platelet Factor V Release and Activation. $292 \mu 1$ of platelet suspension $(5.5 \times 10 / \mathrm{ml})$ were incubated with $13 \mu 1$ of $75 \mathrm{mM} \mathrm{CaCl}$, and stirred ( 350 revolutions/min) for $3 \mathrm{~min}$ at $37{ }_{\mathrm{C}}$ followed by the addi tion of thrombin, resulting in a final volume of $350 \mu 1$. Subsequently, aliquots (usually $20 \mathrm{\mu l}$ ) were taken and incubated with factor $\mathrm{Xa}(1.3 \mathrm{x}$ $\left.10^{-1} \mathrm{M}\right)$, phospholipid ${ }_{5}$ containing $20 \%$ phosphatidylserine and $80 \%$ phosphatidylcholine $\left(1.0 \times 10^{-5} \mathrm{M}\right)$ and $\mathrm{CaCl}_{2}(10 \mathrm{mM})$ in a buffer containing $50 \mathrm{mM}$ Tris, $175 \mathrm{mM} \mathrm{NaCl}$ and $0.5 \mathrm{mg} / \mathrm{ml} \mathrm{HSA}$, $\mathrm{pH} 6.7$ in a final volume of $0.225 \mathrm{ml}$ for $5 \mathrm{~min}$ at $37{ }^{\circ} \mathrm{C}$ in a plastic cuvette. The reaction was initiated by the addition of $25 \mu 1$ of prothrombin $\left(2.0 \times 10^{-6} \mathrm{M}\right)$. After $2 \mathrm{~min}, 0.65 \mathrm{ml}$ of the same buffer containing $20 \mathrm{mM}$ EDTA and $0.24 \mu \mathrm{mol}$ S2238 was added to the reaction mixture. The amount of thrombin formed was measured by the change in absorbance recorded on an Aminco DW2 spectrophotometer operating in the dual wave-length mode $\left(\lambda_{\mathrm{S}}=405 \mathrm{~nm}\right.$ and $\left.\lambda_{\mathrm{r}}=500 \mathrm{~nm}\right)$ thermostated at $37{ }^{\circ} \mathrm{C}$. Standard curves were constructed by assaying dilutions of a bovine factor $\mathrm{Va}$ preparation whose concentration was determined utilizing active site titrated factor $\mathrm{Xa}(9)$. The assay had a functional range from $2 \times 10^{-14} \mathrm{M}$ to $1 \times 10^{-12} \mathrm{M}$ of factor Va.

Platelet Beta-Thromboglobulin (BTG) Release. To a reaction tube containing $292 \mu 1$ of a platelet suspension $(5 \times 10 / \mathrm{ml}), 13 \hat{\mu} 1$ of $75 \mathrm{mM} \mathrm{CaCl}$ was added. The tube content was stirred for $5 \mathrm{~min}$ at $37{ }^{\circ} \mathrm{C}$ and platelet activation was 
started by addition of a platelet activator (thrombin or collagen) resulting in a final volume of $350 \mu 1$. After a variable time periode at $37{ }^{\circ} \mathrm{C}$, the release reaction was stopped by adding to the platelet suspension $56 \mu 1$ Hepes buffer containing $135 \mathrm{mM}$ formaldehyde, $100 \mathrm{mM}$ EDTA, and bringing it to a melting ice-bath (12). Platelets were centrifuged for 1 min in an Eppendorf centrifuge 5412, $200 \mu 1$ of the supernatant was carefully removed, to which $50 \mu 1$ of a $2 \mathrm{M}$ Tris solution was added to neutralize the excess of formaldehyde. The sample was diluted 1:3 in Hepes buffer pH 7.5 containing $20 \%$ of horse serum and the amount of BTG was measured using the BTG radioimmunoassay kit from Amersham International Limited according to the instruction of the manufacturer.

Determination of Platelet Prothrombin Converting Activity (PPCA). $292 \mu 1$ of platelet suspension $(5 \times 10 / \mathrm{ml})$ were incubated with $13 \mu \mathrm{l}$ of $75 \mathrm{mM} \mathrm{CaCl}_{2}$ and stirred for $3 \mathrm{~min}$ at $37^{\circ} \mathrm{C}$. Platelet stimulation was started by adding thrombin or collagen plus thrombin resulting in a final volume of $325 \mu 1$ and $\mathrm{a} \mathrm{CaCl}_{2}$ concentration of $3 \mathrm{mM}$. After a variable time of stirring at 37 ${ }_{C}$ (i.e. platelet trigger time) the PPCA was determined as follows. $50 \mu 1$ factor $\mathrm{Va}(5 \mathrm{nM})$ and $50 \mu 1$ factor $\mathrm{Xa}(10 \mathrm{nM})$ were added to the triggered platelet suspension, to allow equilibration with the platelets. After 2 min period of preincubation, prothrombin activation was started with the addition of $75 \mu 1$ of a prepared mixture containing $6.6 \mu \mathrm{M}$ prothrombin and $27 \mathrm{mM}$ $\mathrm{CaCl}_{2}$ in $50 \mathrm{mM}$ Tris, $175 \mathrm{M} \mathrm{NaCl}$ and $0.5 \mathrm{mg} / \mathrm{ml} \mathrm{HSA}$, $\mathrm{pH} 7.9$, to result in a final volume of $0.5 \mathrm{ml}$. The final concentrations of the reactants were: 0.5 $\mathrm{nM}$ factor $\mathrm{Xa}, 1 \mathrm{nM}$ factor $\mathrm{Va}, 1 \mu \mathrm{M}$ prothrombin and $6 \mathrm{mM} \mathrm{CaCl}$. After 30 and $60 \mathrm{~s}$ aliquots (usually $10 \mu \mathrm{l}$ ) were taken from the reaction mixture to determine the amount of thrombin formed.

Analysis of the Data. We assumed that thrombin forms a complex with heparin and that such a complex has no enzymatic activity. The reversible association between heparin and thrombin is expressed as:

$$
\mathrm{K}_{\mathrm{d}}=[\mathrm{H}][\mathrm{IIa}] /[\mathrm{H} \cdot \mathrm{IIa}]
$$

where [H] is the free heparin concentration and [IIa] is uncomplexed thrombin. Because heparin is present in excess over thrombin, [H] can be equaled to the heparin concentration added. Since the initial rate of factor Va generation (v) is directly proportional to the uncomplexed thrombin concentration:

$$
\mathrm{v}=\mathrm{k}[\mathrm{IIa}]=\mathrm{k}\left([\mathrm{IIa}]_{0}-[\mathrm{H} \cdot \mathrm{IIa}]\right)
$$

where [IIa] $]_{0}$ is the initial thrombin concentration. From (1) and (2) we find:

$$
\mathrm{v} /\left(\mathrm{v}_{\mathrm{o}}-\mathrm{v}\right)=\mathrm{K}_{\mathrm{d}} \cdot(1 /[\mathrm{H}])
$$
where $v_{0}=k[I I a]$, is the initial rate of factor $v a$ generation in the
absence of heparin. A plot of $v^{\prime}\left(v_{0}-v\right)$ versus the reciprocal heparin concentration gives a straight line with slope $K_{d}$. Since $K_{d}$ is the amount of heparin required to bind half the thrombin, the $\mathrm{K}_{\mathrm{d}}$ value can also be expressed as $\mathrm{IC}_{50}$, the amount of heparin causing $50 \%$ inhibition. 


\section{RESULTS}

Inhibition of Platelet Factor V Release and Activation by Heparin and Heparin Fractions. Factor $V$ is released from the $\alpha$-granules as a profactor We determined that our assay is virtually a quantitative assessment of the presence of factor $\mathrm{Va}$, rather than factor $\mathrm{V}$ activity, i.e. under the assay conditions factor $V$ activity is $1.3 \%$ of factor $V$ a activity (data not shown). The initial rate of factor Va activity generation after triggering the platelets with thrombin, appeared to be proportional with the thrombin concentration up to $1.0 \mathrm{nM}$. The maximal amount of factor $\mathrm{Va}$ that could be generated was about $1 \mathrm{ng} / 1.6 \times 10^{6}$ platelets (Figure 1). This is similar to the amount of platelet factor V Tracy et al. (15) reported for Triton-lyzed platelets.

To study the effects of heparin and heparin fractions on the initial rate of platelet factor Va generation, $4.6 \times 10^{\circ}$ platelets $/ \mathrm{ml}$ were stimulated with $0.5 \mathrm{nM}$ thrombin and the amount of factor $\mathrm{Va}$ formed was determined by assaying samples taken 3 min after initiating the release. It is important to note that under these conditions the rate of factor Va generation is proportional to the functional thrombin concentration (Figure 1 ).
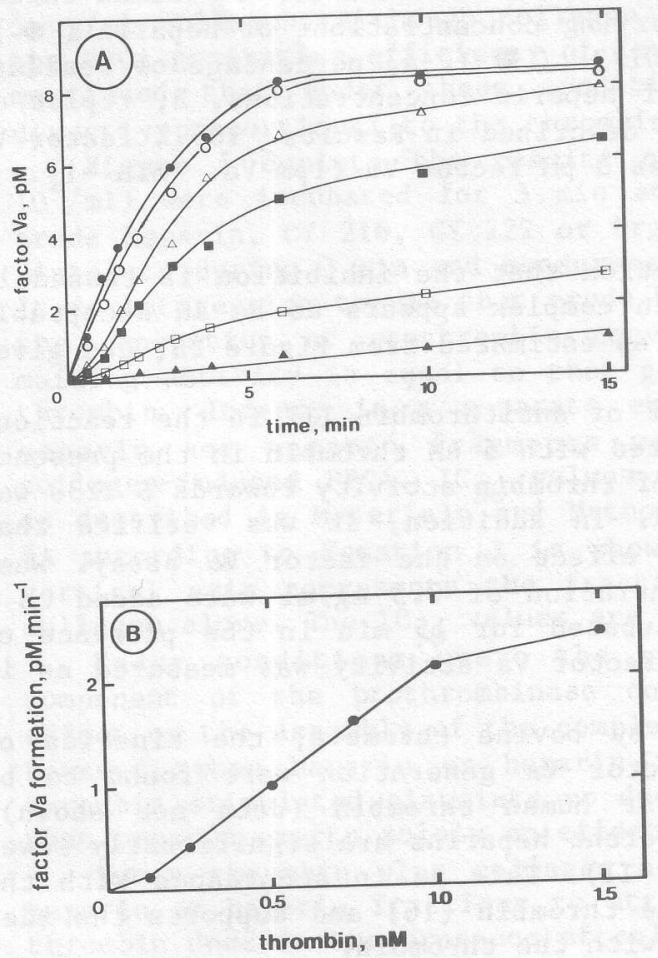

FIG. 1

Effect of varying thrombin concentrations on the time course of factor Va generation. A, platelets $\left(4.6 \times 10^{6} / \mathrm{m} 1\right)$ were incubated at $37{ }^{\circ} \mathrm{C}$ with varying thrombin concentrations $(\Delta, 0.125 \mathrm{nM} ; \square$
$0.25 \mathrm{nM} ; 0.5 \mathrm{nM}, \Delta, 0.75 \mathrm{nM} ; 0,1$ $\mathrm{nM} ; 0,1.5 \mathrm{nM})$. B, replot of the initial rate of factor $\mathrm{Va}$ formation as a function of thrombin concentration.

The influence of varying amounts of crude heparin, CY 216 , CY 222 and org 10172 on the initial rate of factor $\mathrm{Va}$ generation is shown in Figure 2A. It is apparent that crude heparin is the most potent inhibitor. When the data from Figure $2 \mathrm{~A}$ were replotted according to Equation 3 (see Materials and Methods) straight lines were obtained going through the 

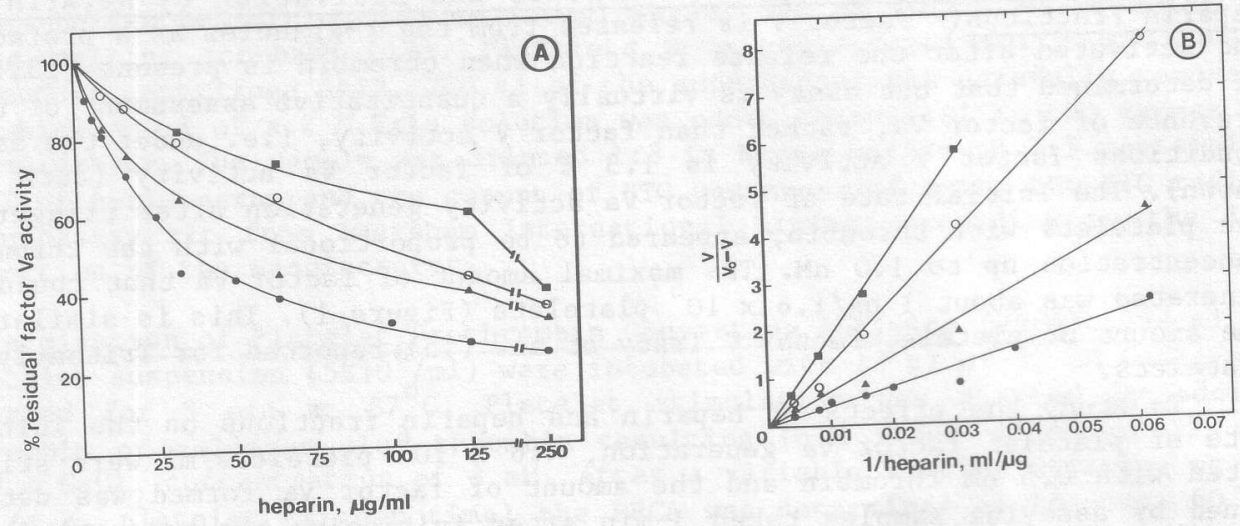

FIG. 2 Effect of heparin (fractions) on thrombin induced platelet factor Va
generation. Platelets $(4.6 \times 10 \% \mathrm{~m}$ ) were stirred with $0.5 \mathrm{nM}$ human thrombin for $3 \mathrm{~min}$, in the presence of varying concentrations of heparin ( ) ,

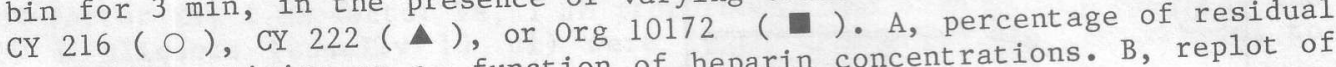
factor $\mathrm{Va}$ activity as a function of heparin concentrations. B, replot of the data according to Equation 3 as described in Results. $100 \%$ factor Va activity in the absence of heparin was $3 \mathrm{pM}$ factor $\mathrm{Va}$ ( $1 \mathrm{pm} \mathrm{Va}$. min -1).

origin (Figure 2B). Thus, our assumption that the inhibition is caused by the formation of the heparin-thrombin complex appears to be an acceptable minimal hypothesis. The $\mathrm{IC}_{50}$ values, as estimated from Figure $2 \mathrm{~B}$, are given in Table I.

We could exclyde the involvement of antithrombin III in the reaction. When platelets $(10 / \mathrm{m} 1)$ were stimulated with $5 \mathrm{nM}$ thrombin in the presence of crude heparin $(10 \mu \mathrm{g} / \mathrm{m} 1)$ no loss of thrombin activity towards $\mathrm{S} 2238$ was observed over a 20 min time period. In addition, it was verified that heparin or heparin fractions had no effect on the factor $V a$ assay. When heparin(fractions) at a final concentration of $0.5 \mathrm{mg} / \mathrm{m} 1$ were added to a platelet suspension $(4.6 \times 10 \% \mathrm{ml})$ incubated for $15 \mathrm{~min}$ in the presence of $0.5 \mathrm{nM}$ thrombin, the same level of factor Va activity was measured as in the absence of heparin.

If human thrombin was replaced by bovine thrombin, the kinetics of bovine thrombin-induced platelet factor Va generation were found to be identical to those reported here for human thrombin (data not shown). However, the $\mathrm{IC}_{50}$ values for the different heparins are significantly lower than those for human thrombin (Table II). This is in accordance with the higher affinity of heparin for bovine thrombin (16) and supports the idea that the heparins interact primarily with the thrombin.

Effect of Heparin on Platelet Beta-Thromboglobulin Release. In order to investigate if any interaction between platelets and heparin, might result in an impaired release reaction, we studied the release of another platelet alpha-granule protein, BTG. Platelets $(4.6 \times 10 / \mathrm{m} 1)$ were incubated with 10 $\mu \mathrm{g}$ collagen/ml or with $0.5 \mathrm{nM}$ thrombin either in the absence or presence of crude heparin $(0.1 \mathrm{mg} / \mathrm{ml})$. When platelets were stimulated by collagen, 
heparin had no effect on the kinetics of BTG release, whereas heparin ( 100 $\mu \mathrm{g} / \mathrm{m} 1$ ) diminished BTG release to less than $10 \%$ of the control value if thrombin was used to stimulate the platelets.

Effect of Heparin and Heparin Fragments on the Generation of Platelet Activity in Prothrombin Activation. Platelet prothrombin converting activity (PPCA) was measured under conditions where added factor Va exceeded greatly the amount of factor Va that was generated from platelets, so as to make the test independent of factor $V$ release. By ommiting phospholipids from our assay, the rate of thrombin formation becomes directly proportional to the amount of procoagulant surface that was generated upon platelet stimulation. It has been shown that platelets activated by a combination of collagen plus thrombin form a more suitable catalytic surface for the prothrombinase complex then platelets treated with thrombin alone (17). Therefore, we investigated the effect of heparins on human thrombin plus collagen-induced PPCA. Conditions had to be found where PPCA generation is linear in time and directly proportional to the thrombin concentration. The generation of a procoagulant surface was followed in time for platelets $\left(4.6 \times 10^{6} / \mathrm{ml}\right)$ stimulated with thrombin $(0.3 \mathrm{nM})$ plus collagen $(5 \mu \mathrm{g} / \mathrm{ml})$ (Figure 3$)$. The dependency of platelet activation on the thrombin concentration is shown in Figure 4, either in the absence or presence of $5 \mu \mathrm{g} / \mathrm{ml}$ collagen. As a standard procedure to study the effect of heparin, platelets were stimulated for 3 min with $0.3 \mathrm{nM}$ thrombin plus $5 \mu \mathrm{g} / \mathrm{ml}$ collagen. Although collagen had to be added in order to potentiate the PPCA generating efficiency of low thrombin concentrations, it has to be mentioned that under these conditions the rate of PPCA generation is directly proportional to the thrombin concentration (Figure 4).

Figure 5 depicts the results of experiments where platelets $(4.6 \mathrm{x}$ $10 \% \mathrm{ml}$ ) were incubated for $3 \mathrm{~min}$ at $37^{\circ} \mathrm{C}$ with varying concentrations of crude heparin, CY 216, CY 222 or Org 10172, followed by the stimulation of platelets during $3 \mathrm{~min}$ and measurement of prothrombin converting activity. It is interesting to see that crude heparin is not able to block completely the generation of prothrombin converting activity. Apparently, the remaining activity is equal to that generated by collagen in the absence of thrombin. Indeed, in a separate experiment we found that neither crude heparin nor heparin fragments were able to block the formation of collagen-induced PPCA. IC 50 values were determined by analyzing the data as described in Materials and Methods. The replot of the data from Figure $5 \mathrm{~A}$ according to Equation 3 is shown in Figure 5B. The intercept on the vertical axis represents the fraction of the PPCA activity generated by collagen alone. The $\mathrm{IC}_{50}$ values are listed in Table I.

Under conditions where the procoagulant surface is the limiting component of the prothrombinase complex, heparin might have as well an effect on the assembly of the complex and so affecting the PPCA assay (17). However, when heparin or heparin fractions were added to collagen plus thrombin stimulated platelets no decrease in PPCA was observed, indicating that heparin exerts solely an effect on the generation of PPCA (Table III). Human thrombin plus collagen acting on human platelets requires more heparin or heparin fractions to attain $50 \%$ inhibition of PPCA than bovine thrombin does in the presence of collagen (Table II). 

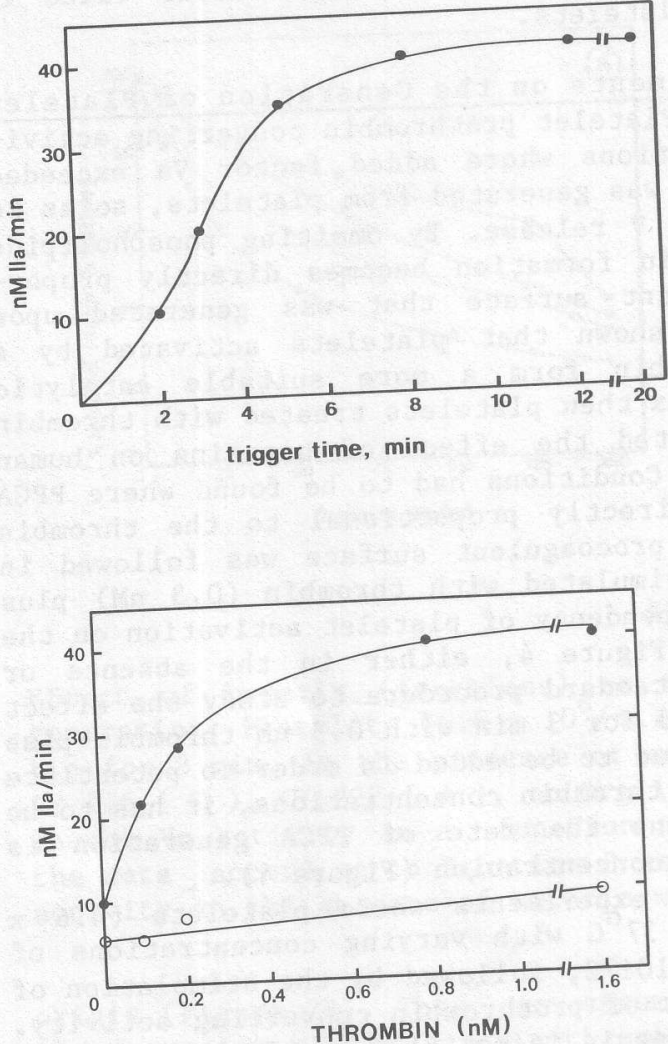

FIG. 3

Time course of appearance of PPCA. Platelets $(4.6 \times 10 . \% / \mathrm{ml})$ were incubated at $37^{\circ} \mathrm{C}$ with $0.3 \mathrm{nM}$ human thrombin and $5 \mu \mathrm{g} / \mathrm{ml}$ collagen. At different trigger times, coagulation factors Xa, Va and prothrombin were added and thrombin formation was assayed as described in Material and Methods.

FIG. 4

PPCA generation as a function of human thrombin concentrations. Platelets $(4.6 \times 10 \% / \mathrm{m} 1)$ were triggered at $37^{\circ} \mathrm{C}$ for 5 min with varying human thrombin concentrations in the absence ( 0 ) or in the presence ( $\bullet$ ) of $5 \mu \mathrm{g} / \mathrm{m} 1$ collagen. Thrombin formation was assayed as described in Material and Methods.
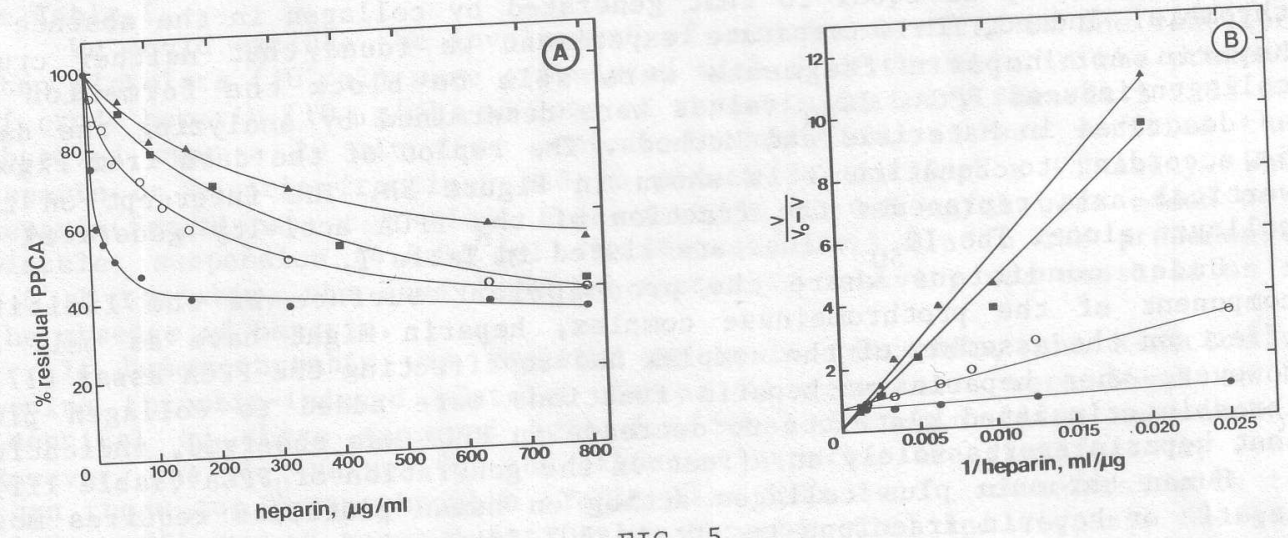

FIG. 5

Effect of heparin(fractions) on thrombin plus collagen-induced PPCA. platelets $(4.6 \times 10 / \mathrm{m} 1)$ were triggered 3 min with $0.3 \mathrm{nM}$ human thrombin and $5 \mu \mathrm{g} / \mathrm{ml}$ collagen in the presence of varying concentrations of heparin ( - ), CY 216 ( 0 ), CY 222 ( $\Delta$ ), or Org 10172 ( ) ). A, percent age of residual PPCA as a function of heparin concentrations. data as described in Materials and Methods. $100 \%$ PPCA inheparin was $24 \mathrm{nM} \mathrm{IIa/min.}$ 
TABLE I

Effect of Heparin Fractions on Human Thrombin-Induced Factor Va Generation and Human Thrombin Plus Collagen-Induced PPCA

\begin{tabular}{ccc}
\hline Compound & $\begin{array}{r}\text { Factor Va generation } \\
\mathrm{IC}_{50}(\mu \mathrm{g} / \mathrm{ml})\end{array}$ & $\mathrm{IC}_{50}(\mu \mathrm{g} / \mathrm{ml})$ \\
\hline Heparin & 40 & 10 \\
CY 216 & 130 & 100 \\
CY 222 & 70 & 540 \\
Org 10172 & 180 & 440 \\
\hline
\end{tabular}

TABLE II

Effect of Heparin Fractions on Bovine Thrombin-Induced Factor Va Generation and Bovine Thrombin Plus Collagen-Induced PPCA

\begin{tabular}{ccc} 
Compound & $\begin{array}{c}\text { Factor Va generation } \\
\mathrm{IC}_{50}(\mu \mathrm{g} / \mathrm{ml})\end{array}$ & $\mathrm{IC}_{50}(\mathrm{\mu g} / \mathrm{ml})$ \\
\hline Heparin & 0.5 & 3.4 \\
CY 216 & 3.3 & 3.8 \\
CY 222 & 1.8 & 90.0 \\
Org 10172 & 15.0 & 125.0 \\
\hline
\end{tabular}

TABLE III

Effect of Heparin Addition on the Thrombin Plus Collagen-Induced Procoagulant Prothrombin Converting Activity

$\begin{array}{llcc}\text { Compound } & & \begin{array}{c}\text { Rate of } \begin{array}{c}\text { thrombin formation } \\ \text { (nM/min) }\end{array} \\ \text { None }\end{array} & \begin{array}{c}\text { PPCA } \\ (\%)\end{array} \\ \text { Heparin } & (640 \mu \mathrm{g} / \mathrm{ml}) & 24.0 & 100 \\ \text { CY } 216 & (1000 \mu \mathrm{g} / \mathrm{ml}) & 24.0 & 100 \\ \text { CY } 222 & (1000 \mu \mathrm{g} / \mathrm{ml}) & 22.4 & 92 \\ \text { Org } 10172 & (1000 \mu \mathrm{g} / \mathrm{ml}) & 23.4 & 96 \\ \end{array}$




\section{DISCUSSION}

The heparin preparations that are in general use at this moment are extremely complex mixtures with components that differ with respect to molecular weight, chemical composition, secondary structures as we11 as antithrombin III affinity and other biological properties. It is not surprising that, besides the well known antithrombin III potentiating effect many other inhibitory actions on the haemostatic system can be found. Crude heparin shows a marked anticoagulant and antithrombotic, but also a hemorrhage-inducing effect. It was generally assumed that these three effects were intimately linked. More recent ly it has been shown that these three biological functions of crude heparin can to a large extent be dissociated $(1-5)$. This suggests that different fractions of crude heparin can have different effects as to anticoagulation, antithrombotic action and the induction of hemorrhages. This is extremely interesting and of great practical interest because, where antithrombotic action is pursued and hemorrhage must be avoided, the therapeutic ratio between the two actions is always estimated on basis of anticoagulant action.

However, the relationship between in vitro kinetics as assessed by clotting assays and the antithrombotic action of heparin is far from being understood. Although binding to antithrombin III plays an imported role in the antithrombotic action of heparin, low-affinity heparin seems to contribute to the anti-thrombotic action of heparin (19).

Although platelets are essential to the process of blood coagulation, no data are available on the effects of heparin or heparin fractions on the generation of platelet procoagulant activities. The present study was undertaken to assess the effects of crude heparin, different heparin fractions and a heparinoid on thrombin-induced platelet factor Va generation and thrombin plus collagen-induced platelet prothrombin converting activity (PPCA).

Heparin $I_{50}$ values were determined under conditions where both initial rates of platelet factor $\mathrm{Va}$ and platelet PCA generation, were directly proportional to the thrombin concentration. The assumption was made that thrombin, when complexed with heparin, has no activity towards macromolecular substrates. Our experimental data appear to be consistent with that model (Figures 2D and 5B).

An interesting observation was the absence of effect of heparin (fractions) on the assembly and functioning of the prothrombinase complex at the outer membrane of activated platelets (Table III). This seems to be in contrast with the findings of Walker et al. (18). They reported that heparin inhibited prothrombin activation by preventing the binding of activated clotting factors as well as prothrombin to a phospholipid surface. When we performed equilibrium binding studies according to Van de Waart et al. (20) we found that crude heparin $(100 \mu \mathrm{g} / \mathrm{ml})$ did not change the affinity of factor $\mathrm{Va}$, factor $\mathrm{Xa}$ and prothrombin to phospholipid as well as total phospholipids binding capacity (to be published).

Thrombin-induced platelet factor $\mathrm{Va}$ generation is the result of release of the non-activated factor and subsequently activation by thrombin. Because our factor $V a$ assay is insensitive for factor $V$ the inhibitory action of heparin on the release reaction could not be separated from its action on thrombin-catalyzed factor $V$ activation. However, we demonstrated that heparin did inhibit the thrombin-induced beta-thromboglobulin release, whereas heparin did not inhibit the collagen-induced beta-thromboglobulin release. This supports the notion that heparin exerts its effect through a heparin-thrombin rather than through a heparinplatelet interaction. 
As to the $I_{50}$ values measured for the different heparins in the two thrombin-induced platelet reactions, it is obvious that for crude heparin relatively low $I_{50}$ values were found, compared to CY 216 , CY 222 and Org
10172 . Therefore, on a weight basis ( $\mu \mathrm{g} / \mathrm{m} 1)$ crude heparin is a more potent inhibitor of both factor Va and PCA generation. The inhibitory capacity of a heparin fraction on thrombin induced reactions of platelet activation is not always in accordance with its antithrombin III-dependent antithrombin specific activity (anti-IIa $\mathrm{U} / \mathrm{mg}$ ). Moreover when $\mathrm{IC}_{50}$ values are given in anti-IIa U/ml, no correlation is found. This strongly suggests that, in studying the inhibitory action of heparin on thrombin, an antithrombin III-dependent effect can be distinguished from an independent one.

As yet, we can only speculate about the occurrence in different heparin molecular species, of such differential antithrombin actions. It would be interesting to establish whether or not low-affinity heparins have antithrombin activities in platelet reactions as studied in the present report.

\section{ACKNOWIEDGEMENTS}

We thank Mrs. T. Camphuisen for typing the manuscript.

D. Baruch was supported by a grant from Institut National de la Santé et de la Recherche Médicale (France).

\section{REFERENCES}

1. CARTER, C.J., KELTON, J.G., HIRSH, J., CERKUS, A., SANTOS, A.V. and GENT, M. The relationship between the hemorrhagic and antithrombotic properties of low molecular weight heparin in rabbits. Blood 59: $1239-1245,1982$.

2. THOMAS, D.P., MERTON, R.E., BARROWCLIFFE, T.W., THUNBERG, L. and LINDAHL, U. Effects of heparin oligosaccharides with high affinity for antithrombin III in experimental venous thrombosis. Thrombos.Hemostas. 47: 244-248, 1982 .

3. HOLMER, E., MATTSON, C. and NILSSON, S. Anticoagulant and antithrombotic effects of heparin and low molecular weight heparin fragments in rabbits. Thromb.Res. 25: 475-485, 1982 .

4. OCKELFORD, P., CARTER, C.J., CERSKUS, A., SMITH, C.A. and HIRSH, J. Comparison of the in vivo hemorrhagic and antithrombotic effects of a low antithrombin III affinity heparin fractions. Thromb.Res. 27: $679-690,1982$.

5. HIRSH, J. Heparin induced bleeding. Nouv.Rev.Fr.Haematol. 26: 261-266, 1984.

6. COMFURIUS, P. and ZWAAL, R.F.A. The enzymatic synthesis of phophatidylserine and purification by CM-cellulose column chromatography. Biochim.Biophys.Acta 483: 36-42, 1977.

7. ROSING, J., TANS, G., GOVERS-RIEMSLAG, J.W.P., ZWAAL, R.F.A. and HEMKER, H.C. The role of phospholipids and factor $\mathrm{Va}$ in the prothrombinase complex. J.Biol.Chem. 255: 274-283, 1980.

8. BOTTCHER, C.J.F., van GENT, C.M. and PREIS, C.A. Rapid and Sensitive sub-micro phosphorus determination. Anal.Chem.Acta 24: 203-207, 1961. 
9. LINDHOUT, T., GOVERS-RIEMSLAG, J.W.P., van de WAART, P., ROSING, J. and HEMKER H.C. Factor Va - factor Xa interaction. Effects of phospholipid vesicles of varying composition. Biochemistry 21: 4594-5502, 1982.

10. PLETCheR, C.H. and NELSESTUEN, G.L. The rate determining step of the heparin-catalyzed antithrombin-thrombin reaction is independent of thrombin. J.Biol.Chem. 257: 5342-5345, 1982.

11. Van DIEIJEN, G., TANS, G., ROSING, J. and HEMKER, H.C. The role of phospholipid and factor VIIIa in the activation of bovine factor $X$. J.Biol.Chem. 256: 3433-3442, 1981 .

12. AKKERMAN, J.W.N., GORTER, G. and KLOPROGGE, E. Kinetic analysis of a granule secretion by platelets; a methodological report. Thromb.Res. 27: $59-64,1982$.

13. CHESNEY, C.M., PIFER, D. and COLMAN, R.W. Subcellular localization and secretion of factor V from human platelets. Proc.Nat.Acad.Sci. 78: $5180-5184,1981$.

14. KANE, W.H., LINDHOUT, T., JACKSON, C.M. and MAJERUS, P.W. Factor Va dependent binding of factor Xa to human platelets. J.Biol.Chem. 255: $1170-1174,1980$.

15. TRACY, P.B., GILES, A.R., MANN, K.G., EIDE, L.L., HOOGENDOORN, H. and RIVARD, G.E. Factor V (Quebec): A bleeding diathesis associated with a qualitative platelet factor $\mathrm{V}$ deficiency. J.Clin.Invest. 74: 1221-1228, 1984.

16. DENSON, K.W.E. The sensitivity of human and bovine thrombin to heparin in plasma. Thromb.Res. 23: 207-213, 1981.

17. BEVERS, E.M., COMFURIUS, P., van RIJN, J.L.M., HEMKER, H.C. and ZWAAL, R.F.A. Generation of prothrombin converting activity and the exposure of phosphatidylserine at the outer surface of platelets. Eur.J.Biochem. 122: 429-436, 1982 .

18. WALKER, F.J. and ESMON, C.T. Interactions between heparin and factor Xa. Inhibition of prothrombin activation. Biochim.Biophys.Acta 585: 405-415, 1979.

19. MERTON, R.E., THOMAS, D.P., HAVERCROFT, S.J., BARROWCLIFFE, T.W. and LINDAHL, U. High and low affinity heparin compared with unfractionated heparin as antithrombotic drugs. Thrombos.Hemostas. 51: 254-256, 1984.

20. Van de WAART, P., BRULS, H., HEMKER, H.C. and LINDHOUT, T. Interaction of bovine blood clotting factor $\mathrm{Va}$ and its subunits with phospholipid vesicles. Biochemistry 22: 2427-2432, 1983. 